\title{
Chapter Sixteen
}

\section{The ACT Human Rights Act 2004 and the Commonwealth Anti-Terrorism Act (No 2) 2005: A Triumph for Federalism or a Federal Triumph?}

\author{
Andrew Byrnes ${ }^{*}$ and Gabrielle McKinnon ${ }^{* *}$
}

\section{Introduction}

In 2004 the Legislative Assembly of the Australian Capital Territory (ACT) enacted the first modern bill of rights adopted by any jurisdiction in Australia. The Human Rights Act 2004 (ACT) (HRA) which entered into operation on 1 July 2004 , is a modest endeavour by comparison with many overseas models. ${ }^{1}$ The ACT HRA is a statutory bill of rights closely modelled on the United Kingdom's Human Rights Act 1998 and is thus not entrenched as a constitutional charter; it incorporates a limited range of human rights (the classic civil and political rights contained in the International Covenant on Civil and Political Rights ${ }^{2}$ (ICCPR)); it is primarily an interpretive instrument; and it does not explicitly provide for remedies for violations of the $\mathrm{HRA}^{3}$ (although it does empower the Supreme Court to make a declaration of incompatibility in cases where the Court is unable to construe a statute in accordance with the human rights guaranteed by the Act). The HRA is intended to promote a dialogue on human rights between the various arms of government, but preserves the final say on disputes over the extent of and limitations on rights to democratically elected politicians, and

\footnotetext{
" Professor of International Law, Faculty of Law and Australian Human Rights Centre, The University of New South Wales, Sydney, Australia.

${ }^{* *}$ Research Associate, Regulatory Institutions Network, Centre for International Governance and Justice, The Australian National University, Canberra, Australia.

This chapter forms part of two ARC-funded projects: ARC Linkage Project LP0455490 'Australia's First Bill of Rights: Assessing the Impact of the Australian Capital Territory's Human Rights Act 2004' (with the ACT Department of Justice and Community Safety); and ARC Discovery Project DP0451473 'Terrorism and the Non-State Actor: the Role of Law in the Search for Security'.

${ }^{1}$ For references to primary and secondary materials on the ACT HRA, see the website of the ACT

Human Rights Act Research Project <http://acthra.anu.edu.au/>.

2 International Covenant on Civil and Political Rights, 999 UNTS 171 (entered into force 23 March 1976).

${ }^{3}$ However, a new remedy for contravention of human rights by public authorities was introduced by the Human Rights Amendment Act 2008 (ACT), which will come into force on 1 January 2009.
} 
envisages that the most important way for the HRA to have an impact is to bring about cultural change in government. ${ }^{4}$

Much of the debate around this Bill of Rights, like that about bills of rights in other countries, focused on the implications for the traditional distribution of powers among the organs of the State: to what extent would it disturb the traditional assignment of roles between the legislature, the executive and the courts and, in particular, would it give inordinate power to unelected judges to second-guess and override the decisions of democratically elected legislators? There was less attention given to the impact that the HRA might have on federal law and on the law of other States, though it was hoped that the HRA would break the logjam on the enactment of bills of rights in Australia by showing that it was politically possible to enact a bill of rights and that the sky would not fall in on traditional arrangements if one did so. This hope appears to have been borne out, with the passage of the Victorian Charter of Rights and Responsibilities in 2006, ${ }^{5}$ and the consideration of proposals for bills of rights in Western Australia $^{6}$ and Tasmania. ${ }^{7}$

In this paper we explore the impact of the ACT HRA in one of the recent debates about Australia's anti-terrorism legislation, namely the measures introduced by the former federal government in late 2005 as part of a package agreed with the State and Territory Premiers and Chief Ministers in the aftermath of the London bombings of July 2005. The package contained, among other measures, a legislative regime for preventative detention and control orders, and a revision of existing sedition laws. These proposals were eventually enacted as the Anti-Terrorism Act (No 2) 2005 (Cth), ${ }^{8}$ and as a series of State and Territory enactments giving effect to the agreement between the Commonwealth and the States/Territories, with some variation among the various jurisdictions.

We first outline the role that a federal division of powers may play in providing protection for human rights though its diffusion of political power, and the limitations of this protection in a context of cooperative federalism. We then

\footnotetext{
${ }^{4}$ See J Stanhope, 'The Human Rights Act 2004 (ACT): Making a Stand in the ACT' (2005) 30 Alternative Law Journal 54; C Evans, 'Responsibility for Rights: the ACT Human Rights Act' (2004) 32 Federal Law Review 291; H Charlesworth and G McKinnon, 'Australia's First Bill of Rights: The Australian Capital Territory's Human Rights Act' Centre for International and Public Law, Law \& Policy Paper No 28 (Sydney: Federation Press, 2006).

5 See G Williams, 'The Victorian Charter of Rights and Responsibilities: Origins and Scope' (2007) 26 Melbourne University Law Review 880.

${ }^{6}$ See A WA Human Rights Act: Statement of Intent by the Western Australian Government (May 2007) $<$ http://www.humanrights.wa.gov.au/>, together with a consultation paper and draft Bill for public consultation on the same website.

7 See Tasmanian Law Reform Institute, A Charter of Rights for Tasmania, Issues Paper No 11 (August 2006); Tasmanian Law Reform Institute, A Charter of Rights for Tasmania, Report No 10 (October 2007). 8 See generally the 'The Anti-Terrorism Bill (No 2) 2005', Human Rights Defender (2005 Special Issue); A Lynch and G Williams, What Price Security? Taking Stock of Australia's Anti-Terrorism Laws (Sydney: UNSW Press, 2006) 41-58.
} 
describe the process of the agreement and debates, which led to the enactment of the Commonwealth's Anti-Terrorism Act (No 2) Act 2005, and the process involved in drafting its ACT counterpart, the Terrorism (Extraordinary Temporary Powers) Act 2006. By comparing the content of critical provisions of the draft laws and their final versions, we seek to identify the impact that the express invocation of human rights standards may have had on the process. Finally, we seek to put this analysis in a broader political context, noting the other factors that influenced the debate, and assessing whether the impact of the HRA has been significant in terms of substance either on the federal legislation or in differentiating the human-rights-informed ACT legislation from the federal legislation.

\section{Federalism, Diffusion of Power and Protection of Human Rights}

One of the benefits sometimes claimed for a federal system is that its distribution of power among different governments provides some institutional protection against the abuses of power that can easily arise when it is concentrated in a unitary government. Federal compacts generally embody a bargain over a range of issues between the political communities coming together in a federation. Such agreements are often primarily concerned with the broader interests of those entities and their communities (in the Australian context, trade interests were of particular importance), rather than seeking to protect individuals from the exercise of governmental power that infringes on human rights. Accordingly, protection of the rights of individuals is often a by-product or a subordinate feature of such arrangements. Nevertheless, the potential exists for a demarcation of powers to provide limits on what one government may do to those under its jurisdiction. The extent of protection that this actually provides will depend not just on the formal legal and constitutional arrangements, but also on the political alignment of the different governments and the extent to which they agree upon appropriate policies or the need for cooperative federalism reflected in uniform national legislation and schemes.

The trend towards the greater concentration of power in the central government in countries such as Australia - reflected in the expansive reading of Commonwealth legislative powers since Federation and the de facto power that comes from significant control over the finances of the nation ${ }^{9}$ — also means that a federal distribution of powers may present less of an impediment to a Commonwealth government intent on pursuing particular policies than it once did. Commonwealth governments on both sides of politics have not scrupled to

\footnotetext{
${ }^{9}$ For a recent overview, see M McHugh, 'The Impact of High Court Decisions on the Governance of Australia' (Speech delivered at the Hal Wootten Lecture 2007, University of New South Wales, 23 August 2007).
} 
use such dominance when their political and policy preferences led them in that direction.

At the same time, the federal system has also shown its potential for high levels of cooperation, in different fields and at different times - something which depends as well on the configuration of governments at national, State and Territory levels. Efforts to work towards uniform or at least consistent schemes of regulation across the country in many areas reflect the increasing integration of the national economy, and constitutional limitations on the power of the Commonwealth and the States mean that in some cases the two levels of government must work closely together to achieve the goals they share. This cooperation may take the form of uniform national legislation, a combined legislative scheme where federal legislation is supplemented by State legislation that mirrors or complements the federal legislation, or referral to the Commonwealth by the States of particular subjects of legislative power.

It has become more common for States to refer aspects of their legislative powers to the Commonwealth to allow for Australia-wide regimes in areas where Commonwealth power is piecemeal. In recent years referrals have been negotiated in relation to corporations, child custody, de facto relationships and the first raft of counter-terrorism laws. Although the Territories derive their powers of self-government from the Commonwealth rather than the Constitution (and the Commonwealth retains the power to legislate for the Territories without need for referral of powers), they have been included in the cooperative process.

There are a number of bodies in which this formal collaboration between the Commonwealth and State/Territory governments take place. Of particular importance for legal developments are the Council of Australian Governments (COAG) and the Standing Committee of Attorneys-General (SCAG). But the collaboration and debate over policy coordination takes place at many other levels as well.

This chapter looks at one particular instance of Commonwealth-State collaboration, namely the effort to enact wide-ranging amendments to anti-terrorism law, which were initiated by the Commonwealth government during 2005. The measures, which included preventative detention and control order regimes, relied upon the continuation of the referral of State powers in relation to terrorism to the Commonwealth, and the enactment of complementary State and Territory legislation. Such legislation was necessary first to apply the new provisions to State and Territory law enforcement agencies and, second, to overcome perceived constitutional limitations on the Commonwealth in relation to certain aspects of the preventative detention regime (in particular the extension of the administrative detention of a person for more than 48 hours up to a 
maximum of 14 days). ${ }^{10}$ Quite apart from these legal reasons, both federal and State leaders faced the political imperative of being seen to act decisively and, when the Commonwealth was able to argue that there were credible threats that needed to be addressed, State and Territory leaders had little option but to go along with the general thrust of the proposals, since none of them could afford to be left out.

\section{The ACT Human Rights Act 2004}

When the ACT Human Rights Act was enacted in 2004, some commentators saw it as an illustration of another advantage of a federal system, namely the opportunity for experimentation that allows the effect of an initiative to be explored in one jurisdiction without adopting it across the nation (which would in this case not have been possible in any event, due to the opposition of the former federal government to a bill of rights): a successful initiative in one jurisdiction might be taken up by other jurisdictions and, ultimately, at a national level. ${ }^{11}$ Supporters of bills of rights also hoped that the ACT initiative would break the psychological barrier that seemed to lie in the way of efforts to adopt bills of rights in Australia; recent developments suggest that this may indeed be the case, at least insofar as the ACT legislation has provided encouragement to other States to consider adopting similar models.

Most of the discussion of the ACT HRA proposals concentrated on their likely effect on the distribution of powers among the various arms of government in the ACT, and there was relatively little discussion of the potential impact of a HRA on federal law and the law of other jurisdictions. ${ }^{12}$ However, there was speculation that the HRA might influence federal law and the law of other States and Territories through the institutions of cooperative federalism, in particular COAG and SCAG. If the ACT Government was required to certify that any legislation it enacted as part of a cooperative scheme was compatible with the HRA, it was thought that in uniform scheme negotiations ACT representatives might be able to persuade their federal and State colleagues to adopt an explicit human rights analysis in examining any proposals and that the HRA might provide a point of leverage to ensure that cooperative schemes and legislation were more consistent with human rights standards. ${ }^{13}$

\footnotetext{
${ }^{10}$ See A Lynch and A Reilly, 'The Constitutional Validity of Terrorism Orders of Control and Preventative Detention' (2007) 10 Flinders Journal of Law Reform 105.

${ }^{11}$ See, eg, A Byrnes, 'The ACT Bill of Rights: its Relevance and Potential Effectiveness' (Paper presented at the State Legal Convention, Adelaide, 22-23 July 2004).

12 See the discussion by J Stellios in 'Federal Dimensions to the ACT Human Rights Act' (2005) 47 AIAL Forum 33 (noting the potential impact of the HRA on various cooperative arrangements between the Commonwealth and ACT governments).

${ }^{13}$ In fact it does not appear that this has been the case to any great extent. For example, the negotiation of uniform defamation laws by the Standing Committee of Attorneys-General did not appear to reflect the influence of the ACT HRA. In fact in the explanatory statement to the Civil Law (Wrongs) Amendment Bill 2005 (No 2) (ACT), which introduced the new model provisions, some limitations on human rights
} 
The process leading to the enactment of the federal Anti-Terrorism Act (No 2) 2005 and its State and Territory counterparts provides an interesting case study of the role that federalism - cooperative or otherwise - and the existence of a bill of rights in one Australian jurisdiction can play in moderating the excesses of Commonwealth legislative proposals that make serious inroads into traditional human rights protections. The next section outlines the background to the Commonwealth's legislative proposals and the response by the ACT Government to those proposals. We then examine the way in which the explicit human rights standards contained in the ACT HRA were invoked in an effort to moderate the more excessive provisions proposed by the Commonwealth.

\section{The New Measures}

On 8 September 2005, in the wake of the London bombings of July 2005, the former Prime Minister announced his government's intention to introduce additional anti-terrorism measures ${ }^{14}$ and released details of the proposals for new legislation in anticipation of the coming meeting of COAG later that month. ${ }^{15}$ At the meeting of State and Territory Premiers and Chief Ministers with the then Prime Minister, held on 27 September 2005, the participants adopted a communiqué setting out their consensus on a number of issues relating to efforts to combat terrorism. The day-long meeting included a briefing by the Directors-General of the Office of National Assessments and the Australian Security Intelligence Organisation, which appears to have had a persuasive effect on the leaders. The leaders agreed to a number of proposals to strengthen existing counter-terrorism laws, including the introduction of control orders, as well as a system of preventative detention. ${ }^{16}$ For reasons that reflected constitutional concerns as well as the politics of cooperative federalism, it was necessary for the States to enact complementary legislation, which in some respects simply tracked the Commonwealth legislation, but in other respects would supplement it. It was also necessary for the Commonwealth to secure the consent of at least four States, and the majority of all States and Territories, to amend provisions of the Criminal Code Act 1995 (Cth) (Criminal Code) relating to terrorism that relied in part upon a referral of powers from the States. ${ }^{17}$

\footnotetext{
are justified by reference to the federal nature of Australian government and the legitimate purpose of promoting uniform laws: 4 . See further the discussion in the ACT Scrutiny Committee, Scrutiny Report No 21 (2006) 6-19 and the ACT, Parliamentary Debates, Legislative Assembly, 14 February 2006, 7ff.

14 For an overview of the background to the enactment of the Anti-Terrorism (No 2) Act 2005 (Cth), see Bills Digest, No 64 2005-06, 'Anti-Terrorism (No 2) Bill 2005'.

15 J Howard, 'Counter-Terrorism Laws Strengthened' (Press Release, 8 September 2005).

${ }^{16}$ Council of Australian Governments', Communiqué, Special Meeting on Counter-Terrorism, (27 September $2005)<$ http://www.coag.gov.au/meetings/270905/coag270905.pdf >.

17 Criminal Code Act 1995 (Cth) div 100.8.
} 


\section{The Federal Anti-Terrorism Legislation}

Although the State and Territory leaders were all publicly in agreement with each other at the conclusion of the meeting, it seems that the hothouse environment in which it was held may have pressured some Premiers and Chief Ministers into agreeing to broad-brush proposals to which they might not have consented if they had had further time to consider the issues. At the very least, some State and Territory leaders appeared a little discomfited (or affected to be so in the light of public criticism) when the Commonwealth provided them with the draft federal legislation, which it claimed was giving effect to the COAG agreement; others began to give the proposals more critical scrutiny once public debate took place and criticism of them began to emerge.

Following the COAG meeting, the Commonwealth provided the States and Territories with a draft of the federal legislation on a confidential basis; its intention was, it seems, to introduce a Bill into Parliament that had been cleared by the State leaders and to ensure that the Commonwealth had the numbers to pass amendments to the Criminal Code. The Commonwealth anticipated introducing the Bill into Parliament in early November, and proposed to have it enacted before Christmas, a schedule that allowed very little time for substantive review by the relevant Parliamentary Committee (the Senate Legal and Constitutional Legislation Committee). ${ }^{18}$ It was not clear why the Commonwealth felt that there was no need for broad public consultation on the draft legislation, given its scope and the lengthy and detailed nature of the draft Bill.

The Commonwealth was frustrated in its attempt to minimise public scrutiny of the Bill by the ACT Chief Minister, Jon Stanhope. Stanhope took the view that it was important for there to be adequate public scrutiny of the Bill and earned the ire of the former Prime Minister by releasing the draft Bill ${ }^{19}$ on his own website on 14 October $2005 .^{20} \mathrm{He}$ also commissioned legal opinions on the consistency of the proposed Bill with Australia's international human rights obligations and with the provisions of the ACT HRA. ${ }^{21}$

Stanhope's motivations for the release of the Commonwealth draft doubtless included a genuine concern that legislation of this significance should receive broad-ranging public scrutiny. The decision also needs to be seen in light of what may have been his surprise at the draconian content of the draft legislation and a feeling that it had gone beyond what he understood to have been approved

\footnotetext{
${ }^{18}$ See Senate Legal and Constitutional Legislation Committee, Report on the Provisions of the Anti-Terrorism (No 2) Bill 2005 (2005).

19 Then known as the Anti-Terrorism Bill 2005 (Cth). Version 28 of the Bill (dated 7 October 2005) may be found at <> http://www.chiefminister.act.gov.au/docs/B05PG201_v281.pdf>.

20 'Howard on Attack Over Draft Bill Release', Sydney Morning Herald (Sydney), 15 October 2005.

${ }^{21}$ See the materials at $<$ http://acthra.anu.edu.au/terrorism/index.html $>$.
} 
by COAG (or that where things had been left unclear by COAG, extreme provisions were being proposed). The broader context is also important Stanhope was one of the eight State and Territory Labor leaders opposed to a Liberal government at the federal level. Stanhope had also been critical of a number of aspects of the Howard government's human rights record. ${ }^{22}$ The Howard government had also expressed its hostility to a number of the ACT government's human rights initiatives, even suggesting on various occasions that, notwithstanding the system of self-government given to the ACT in $1988,{ }^{23}$ the Commonwealth might use its plenary legislative power of the Territories under section 122 of the Commonwealth Constitution to override ACT legislation which it considered inappropriate (including the HRA itself), ${ }^{24}$ something that it did do in relation to the Civil Unions Act 2006 (ACT). ${ }^{25}$

Immediately after the COAG meeting, Stanhope explained the basis on which he had approached the meeting and had agreed to the Commonwealth proposals:

I had publicly indicated and released the eight critical human rights safeguards and legal safeguards that the ACT would be seeking to achieve today, particularly in relation to preventative detention. They were a requirement that preventative detention only be applied to people reasonably suspected of having committed or being likely to commit a terrorist offence and where immediate detention was necessary to protect public safety; the Commonwealth has responded positively to that. Effective judicial oversight including the right of detainees to know the reasons for their detention and the right to appeal their detention; that's to be incorporated in the legislation. The principle that detention should be kept to the minimum period consistent with public safety; the period of detention will be determined by a judge and will be a period of

\footnotetext{
${ }^{22}$ The Stanhope government has consistently criticised aspects of the human rights record of the former Howard government, and has contrasted this with the protection of rights in the ACT under the HRA. The treatment of asylum seekers, and of Australian detainees in Guantánamo Bay were often the subject of comment in the ACT Legislative Assembly. On some issues, such as the abolition of the Aboriginal and Torres Straight Islander Commission, the Chief Minister has made specific claims that federal government actions breach the ACT HRA (see Debates of the ACT Legislative Assembly, Week 10, 23 August 2005, 3069). Such statements are, of course, rhetorical, as the Human Rights Act (ACT), being an ordinary statute of the ACT, has no direct application to federal laws on Indigenous issues, or on immigration or external affairs.

${ }^{23}$ See the Australian Capital Territory (Self-Government) Act 1988 (Cth).

24 In a letter to Chief Minister Jon Stanhope dated 30 January 2004, then Prime Minister John Howard stated that it was 'inherently undesirable that a Territory should act unilaterally' by adopting a bill of rights, and noted that his government would 'consider' the Human Rights Bill 2003 (ACT), together with the Sexuality Discrimination Legislation Amendment Bill 2003 (ACT) and the Parentage Bill 2003 (ACT). The Chief Minister commented that ' $[\mathrm{t}]$ his was in reality a very thinly veiled threat to use the Commonwealth's power to interfere with the affairs of the Territory': J Stanhope, 'Stanhope Rejects Call for Federal Intervention' (Press Release, 17 February 2004).

${ }^{25}$ In June 2006, the federal government overrode the Civil Unions Act 2006 (ACT), passed in May 2006, by advising the Governor-General to exercise his power to disallow ACT legislation under sub-section 35(2) of the Australian Capital Territory (Self-Government) Act 1988 (Cth): Commonwealth Special Gazette 2006, No S93, 14 June 2006. See J Stanhope, 'Ruddock's Attacks on ACT Laws Hurt Us All', Canberra Times (Canberra), 25 July 2006.
} 
24 hours up to 14 days. And I'm satisfied with that response. That detainees have access to their lawyer of choice; that will be incorporated in the legislation. That detainees have the right to contact their family and their employers and where relevant, their consulate; those rights will be included within the legislation. The right to humane treatment preferably in accordance with published protocols; the ICCPR and subject to independent monitoring, those are features of the legislation and the [former] Prime Minister has indicated today that the legislation will be monitored by the Ombudsman; there will be a right of appeal to the Ombudsman in relation to the decisions taken and there will be annual parliamentary oversight of the operation of the scheme.

The right to a fair trial in the event that charges are ultimately laid indicating that questioning and the continuation of a criminal investigation through questioning or interrogation would not apply during a period of detention; and that will be the case. And finally I expressed the desire for a sunset clause and that too has been agreed. From the ACT Government's point of view I did come here with significant concerns around preventative detention and whether or not it was proportionate response [sic] to the issue we faced. The Commonwealth has responded to every issue that the ACT Government put on the table and the ACT Government is supporting willingly this new approach to national counter-terrorism. ${ }^{26}$

The effect of Stanhope's release of the draft Bill was to initiate a vigorous public discussion of the Bill, in particular its consistency with human rights norms. ${ }^{27}$ Stanhope took the position that, because the ACT mirror-legislation contemplated under the COAG agreement would need to be consistent with the ACT HRA, it was important for the federal legislation to be consistent with those same standards. That in itself seems unexceptionable, given that the HRA gives effect to international human rights guarantees binding on Australia by virtue of its ratification of the ICCPR and the Howard government had consistently stated its position that counter-terrorism legislation should be (and was) consistent with Australia's international obligations: though the assertion has not always been persuasive in particular cases.

Stanhope also took the opportunity to seek, and make public, advice from a number of external advisers on the human rights and constitutional implications of the Commonwealth draft Bill both before and after he publicly released the Commonwealth draft. ${ }^{28}$ The opinions provided by a number of human rights

\footnotetext{
${ }^{26}$ COAG Joint Press Conference, Parliament House, Canberra, 27 September 2005 $<$ http://www.pm.gov.au/media/Interview/2005/Interview1588.cfm>.

27 See M Grattan, 'Stanhope Fires Up Debate Over Secretive Terror Laws', Sydney Morning Herald (Sydney), 16 October 2005.

28 These included the ACT Human Rights Commissioner. The Chief Minister had also previously sought the advice of the ACT Human Rights Commissioner, Dr Helen Watchirs, on the human rights implications
} 
and constitutional experts (including the present authors) ${ }^{29}$ pointed to a number of inconsistencies between the draft Bill, and the provisions of international human rights treaties and the ACT HRA.

This initial debate - in which many others joined to voice their criticisms of the human rights impact of the Bill - was followed by a review of the Bill as introduced into the Parliament. This Bill contained significant improvements over the draft which was released by Stanhope, with new provisions allowing for merits review of preventative detention by the Administrative Appeals Tribunal, and giving persons subject to interim control orders the right to attend a court hearing to determine whether a final order should be granted, rather than the process taking place in their absence. Nevertheless, the Bill remained draconian in many aspects. The Senate inquiry received submissions and evidence from many participants, many of whom underlined human rights concerns that had already been ventilated in the earlier debate. While some amendments were made to the Bill following the inquiry, a number of provisions of the legislation as enacted still raise considerable concern on human rights grounds.

While there seems little doubt that many of the human rights concerns (based on our common law traditions and the applicable international human rights norms) would have been raised before the Senate Committee when the matter was eventually referred to it, the effect of the Stanhope release - and his invocation of the need to comply with the ACT HRA in agreeing to uniform legislation to be enacted at the Territory level — played a role in focusing attention on these issues earlier than would otherwise have been the case and gave critics of the Bill the opportunity to analyse its provisions in more depth. Since the time originally planned to be given to the legislation was very short and the actual time given was not much greater, the extra time that Stanhope's actions provided for scrutiny appears to have been valuable. ${ }^{30}$

What we see in this case is the use by an individual Chief Minister of the COAG process and the desire to achieve a reasonable degree of uniformity across jurisdictions, to invoke the standards of his jurisdiction in an attempt to lever up the standards of the common scheme. (This presumably occurs in other cases in cooperative federal legislative schemes.) Admittedly, the result was a piece of legislation that had been modified somewhat, but which still gave rise to a number of serious human rights concerns.

of the proposals announced by the Prime Minister on 8 September 2005. Copies of the opinions provided may be found at <http://acthra.anu.edu.au/terrorism/index.html $>$.

29 A Byrnes, H Charlesworth and G McKinnon, 'Human Rights Implications of the Anti-Terrorism Bill 2005' (18 October 2005) <http://acthra.anu.edu.au/media/Advice\%2018\%20oct.pdf>.

30 For references to public comment on the Bill, see Parliamentary Library, 'Proposals to Further Strengthen Australia's Counter-Terrorism Laws', E-Brief issued 6 October 2005 updated 25 November 2005 <http://www.aph.gov.au/library/intguide/LAW/TerrorismLaws.htm>. 
The strategy of the Commonwealth Government involved presenting a proposal for federal legislation, which was extreme in its potential inroads on human rights, and allowing only a limited public consultation and parliamentary process in which the proponents of human rights bore the political onus of demonstrating the excesses of the draft and persuading those in positions of political power to modify them. Although the actions of Jon Stanhope undermined this strategy to some extent, the control by the Howard government of both houses of Parliament meant that once the State Premiers had agreed to the regime, the opportunity to achieve changes to the legislation through the consultation process was restricted. Nevertheless, the early debate generated by the release of the draft Bill may have given more impetus to internal critics within the Liberal-National coalition who were able to bring about some amendments through the discussions within the coalition.

\section{The ACT Legislation}

When it came to the drafting of the ACT mirror-legislation agreed to in the COAG Agreement, the influence of the ACT HRA standards (and the prior political debate) is quite striking. The very title of the draft legislation - the Terrorism (Extraordinary Temporary Powers) Bill 2006 (ACT) — reflected the difference of approach the ACT Government wished to take, one which saw the draconian measures involved as a temporary response to an emergency situation, rather than a statute for all time.

The ACT proposals were first released as an exposure draft in late $2005,^{31}$ underlining the Commonwealth's earlier failure to do the same with its proposals. The content of the legislation was heavily influenced by an attempt to ensure as high a level of consistency with the standards of the HRA/ICCPR as seemed possible, given that the legislation had to start with the basic scheme agreed to at COAG and reflected in the Commonwealth legislation (which had been enacted before the ACT consultation draft was released).

The ACT exposure draft introduced a much higher level of judicial involvement in and scrutiny of the procedures for making preventative detention orders ('PDOs'), for example, by providing that:

- only the Supreme Court could make PDOs, whereas the Commonwealth legislation provided that senior Australian Federal Police members could make interim PDOs;

- a statement of reasons for the making of a PDO had to be provided to the person affected (the Commonwealth legislation required a summary of the grounds for the order to be provided to the person, but this was weakened

\footnotetext{
${ }^{31}$ See $<$ http://www.chiefminister.act.gov.au/docs/TerrorExtraTempPowers-V08\%20Final.pdf $>$.
} 
by an exception allowing the exclusion of information on the basis of national security concerns);

- a PDO could only be made if it were 'the least restrictive means to prevent a terrorist act or the only effective way to preserve evidence' (whereas the Commonwealth test was that it would 'substantially assist in preventing a terrorist act, or is necessary to preserve evidence');

- persons under 18 could not be subject to PDOs (in the Commonwealth legislation children 16 and over could be subject to PDOs);

- limitations on the monitoring of legal communications (there is no such restriction in the Commonwealth legislation);

- an explicit requirement for legal representation to be provided by Legal Aid (the Commonwealth legislation made no mention of this);

- a detainee would be able to tell his or her family of the fact and place of detention (under the Commonwealth legislation he or she is only able to inform family that he/she is 'safe' but 'not able to be contacted for the time being');

- there were no 'disclosure' offences concerning telling another person that someone is detained under a preventative detention order (maximum of five years' imprisonment under Commonwealth legislation); and

- the Public Interest Monitor would represent the public interest at a hearing for a PDO or prohibited contact order (Commonwealth legislation requires only that the Ombudsman be notified when a PDO or prohibited contact order is made).

Many of these changes were among those proposed by the human rights experts whom the Chief Minister had consulted during the process. ${ }^{32}$ However, the exposure draft was not the final step in the process of seeking to ensure human rights compliance. The Chief Minister sought further advice on the question of whether the exposure draft was fully compliant with the provisions of the ACT $\mathrm{HRA}^{33}$ and on 15 December 2005, the exposure draft was referred to the Standing Committee on Legal Affairs of the ACT Legislative Assembly. ${ }^{34}$

The Standing Committee, chaired by ACT Shadow Attorney-General Bill Stefaniak, conducted an examination of the exposure draft, in the course of which it received 20 written submissions and held three days of public hearings in January and February 2006. ${ }^{35}$ Although many witnesses gave evidence about the importance of complying with human rights, media attention focused almost exclusively on the comments of Australian Federal Police Commissioner, Mick

\footnotetext{
32 See ACT, Parliamentary Debates, Legislative Assembly, 15 December 2006, 4932.

33 Ibid 4932; ACT, Parliamentary Debates, Legislative Assembly, 30 March 2006, 826.

34 Parliamentary Debates, above n 32, 4934.

35 Standing Committee on Legal Affairs, Report on Terrorism (Extraordinary Temporary Powers) Bill 2005 - Exposure Draft (2006) Report 3

$<$ http://www.legassembly.act.gov.au/downloads/reports/03AntiTerrorismReport.pdf>.
} 
Keelty, who warned the Committee that inconsistencies between the ACT draft legislation and the federal and State legislation would place the ACT at risk of being targeted by terrorists. ${ }^{36}$

The Committee Report, ${ }^{37}$ which was tabled on 28 February 2006, reflected a somewhat uneasy compromise between the diverse positions of its members. These included those of the Chair, Mr Stefaniak, who strongly endorsed the comments of Commissioner Keelty, and would have preferred that the ACT laws simply follow the New South Wales (NSW) model, ${ }^{38}$ as well as those of Dr Deb Foskey, the Greens MLA, who did not agree that a persuasive case had been made to justify the introduction of PDOs in any form. ${ }^{39}$ Overall, the Committee recommended several changes to the laws to bring them more closely into line with other jurisdictions, and to rectify some perceived anomalies within the Bill. One recommendation of the Committee was to lower the age at which young people could be subject to preventative detention orders, from 18 to 16 years. Surprisingly, Dr Foskey agreed with this recommendation, but on the basis that otherwise children would simply be dealt with under the harsher Commonwealth and NSW regimes. ${ }^{40}$

The ACT Government accepted a number of the proposed changes, although very few of those that might be regarded as regressive in human rights terms (it rejected the recommendation in relation to children) and introduced a revised Bill on 30 March 2006. ${ }^{41}$ This was passed by the Assembly at its next sitting, on 11 May 2006, after three more days of vigorous debate. ${ }^{42}$ The Terrorism (Extraordinary Temporary Powers) Act 2006 commenced operation on 19 May 2006.

\section{Did the Human Rights Act 2004 (ACT) Make a Difference?}

There are a number of levels at which the ACT HRA as deployed by the ACT Chief Minister might have had an impact on legislative processes, in particular:

- in relation to the debate around and content of the Commonwealth proposals which were finally enacted as the Anti-Terrorism Act (No 2) 2005;

\footnotetext{
36 See, eg, 'Canberra is Target for Terror; Soft Laws to Blame: Keelty', Canberra Times (Canberra), 1 February 2006.

37 Standing Committee on Legal Affairs, above n 35.

38 Indeed, on 29 March 2006, the day before the government introduced the Terrorism (Extraordinary Temporary Powers) Bill 2006 (Cth), Mr Stefaniak introduced his own private member's Bill, the Terrorism (Preventative Detention) Bill 2006 (ACT), which he described as essentially identical to the NSW legislation on preventative detention (the Terrorism (Police Powers) Amendment (Preventative Detention) Act 2005 (NSW)): ACT, Parliamentary Debates, Legislative Assembly, 29 March 2006, 725.

39 Standing Committee on Legal Affairs, above n 35, Additional and Dissenting Comments of Dr Deb Foskey, 121 .

40 Ibid 126.

41 Terrorism (Extraordinary Temporary Powers) Bill 2006 (ACT).

42 See ACT, Parliamentary Debates, Legislative Assembly, 9, 10, 11 May 2006.
} 
- by influencing State legislation - in particular the NSW legislation - to diverge from the more draconian provisions of the Commonwealth proposals; and

- by influencing the content of both the ACT exposure draft of December 2005 and the Bill as finally introduced into the Legislative Assembly in 2006.

Attempting to identify the particular contribution of the ACT intervention and legislative framework to the content of the Commonwealth legislation poses methodological problems. Many of the criticisms raised in the public debate over the Anti-Terrorism Bill (No 2) 2005 (Cth) and in the submissions to and report of the Senate Legal and Constitutional Legislation Committee were similar to those made by commentators analysing the proposals in light of the ACT HRA, and it seems likely that many of those criticisms would in any event have been directed against the Commonwealth legislative proposals. This is hardly surprising, given the coincidence of the guarantees in the HRA and the international human rights instruments to which Australia is a party, and which thus are regularly invoked in human rights analyses of federal government bills and policies.

But one tangible contribution of the invocation of the imperatives of the ACT HRA was certainly the additional time that was available for the debate as a result of Jon Stanhope's decision to publish the Commonwealth's draft legislation. Given the relatively short time planned by the Government for public debate and the still short time that was eventually permitted, the additional weeks and the focus that was brought to the proposals by the opinions requested by the Chief Minister made a more intensive scrutiny of the Bill possible. This focus appears to have prompted the changes incorporated into later versions of the Bill, even if it was not reflected in the acceptance by the former federal government of the recommendations of the Senate Committee, which were informed by these human rights criticisms.

So far as the effect on the legislation of other States is concerned, it is equally difficult to identify a particular influence of the ACT intervention or the ACT HRA. What is clear is that the general discussion around the human rights implications of the Commonwealth Bill had an impact on the legislation of at least some States. For example, the NSW legislation enacted in pursuance of the COAG Agreement, the Terrorism (Police Powers) Amendment (Preventative Detention) Act 2005 (NSW) contained a number of provisions not in the Commonwealth legislation that clearly responded to human rights concerns although it contained others such as the extension of preventative detention from 48 hours to 14 days, which cut the other way. ${ }^{43}$ Once again, the period of

${ }^{43}$ See the Second Reading Speech to the Terrorism (Police Powers) Amendment (Preventative Detention) Bill 2005 (NSW): NSW, Parliamentary Debates, Legislative Assembly 7 November 2005, 20008 (Mr Milton Orkopoulos, Minister for Aboriginal Affairs, and Minister Assisting the Premier on Citizenship). 
debate generated by Stanhope's actions may have provided an opportunity for refinement of the NSW proposals, but in the absence of a detailed report on the NSW draft by a Parliamentary Committee, a more direct impact is difficult to trace.

It is in relation to the provisions of the ACT's own draft legislation that the impact of the HRA and its use by the ACT Government can be most clearly seen. ${ }^{44}$ The ACT exposure draft of December 2005 had already taken into account a number of the criticisms from a human rights perspective made of the draft and final Commonwealth proposals and the Senate Committee's report on the Commonwealth Bill, as well as the provisions of legislation enacted by some of the other States (in particular NSW). ${ }^{45}$ Although the Standing Committee process in some ways served as a vehicle for the then federal government and its agencies to exert pressure on the ACT to conform to the regimes of the Commonwealth and other States, very few of these recommendations were accepted by the Government in the final 2006 Bill when it was introduced into the Assembly. ${ }^{46}$

The ACT exposure and final draft Bills thus departed significantly from the draft and enacted Commonwealth proposals, in ways that sought to align the ACT proposals with the standards of the ACT HRA. The NSW legislation also sought to alleviate some of the problems with the federal legislation, for example, by providing that the process of granting preventative detention orders was a judicial one at all stages. However, the final ACT Bill went further than the NSW improvements, in an effort to further strengthen the human rights consistency of the ACT Bill.

\section{Assessment}

It is clear that the existence of the ACT HRA played a significant role in the debate over the 2005-2006 anti-terrorism legislative measures. However, the mere existence of a law on the statute books does not of itself generate a particular result, and it seems that a number of factors contributed to the manner in which the process has unfolded. These include:

\footnotetext{
44 A comparison of the provisions of the Commonwealth Act and the ACT Bill shows that there were a number of differences of substance between the two pieces of legislation. See the table prepared by the ACT Department of Justice and Community Service, which appears in the report of the Committee: 'Appendix 3 - Anti-Terrorism Legislation Comparative Provisions', in Standing Committee on Legal Affairs, above n 35, 132-40

45 The Chief Minister stated: 'The provisions in the exposure draft that relate to preventative detention have been modelled on the parts of the State bills that are considered the best in terms of human rights compatibility, constitutionality and adherence to established principles of justice. Additional safeguards, including some contained in the legislation of the other States, have also been incorporated in the exposure draft to ensure that the ACT has the best and most human rights compatible legislation. Making the bill compatible with Australia's international human rights obligations has not altered the effectiveness of the law or limited its reach. It remains consistent with the COAG agreement.' ACT, Parliamentary Debates, Legislative Assembly, 15 December 2006, 4932.

46 ACT, Parliamentary Debates, Legislative Assembly, 30 March 2006, 822.
} 
- the personal commitment by the ACT Chief Minister to the promotion of fundamental human rights principles and the ACT HRA in particular;

- concern about the desirability of enacting wide-ranging anti-terrorism legislation;

- the political oppositional stance of the ACT government on issues of human rights, including the bills of rights issue and the need for extraordinary anti-terrorism powers, and the political advantage that might be gained from putting the federal government under pressure on the issue;

- the requirement imposed by the ACT HRA for a 'compatibility statement' in relation to all new ACT legislation; and

- the impact of the external debate and critique of the various legislative proposals.

Although the ACT HRA appeared to have only an indirect influence on the federal legislation enacted as part of this cooperative regime, this may partly reflect the status of the ACT as a Territory. Had such human rights objections been raised by a State, the Commonwealth may have been forced to make further concessions in order to rely upon a referral of powers from the States in relation to terrorism. Under s 100.8 of the Criminal Code, the agreement of at least four States was required before the Commonwealth could make amendments to Part 5.3 of the Code (terrorism-related offences), but it would also have been open to a State to withdraw its referral of powers: a move that may have created some difficulty for the validity of the Commonwealth legislation within that State. ${ }^{47}$ The momentum that seems to be gathering among the States towards the acceptance of bills of rights, following the example of the ACT and now Victoria, may mean that much greater pressure for human rights compliance will be brought to bear in such cooperative arrangements in the future.

At the end of the day, the ACT, like the other jurisdictions, did not escape a system of preventative detention, and its residents can be subjected to Commonwealth control orders and sedition laws, amongst other provisions. Concerns about the possibility of overreaching in exercise of the powers granted under the new legislation have been confirmed in the public mind by the handling of investigations such as that into the connections of Dr Mohamed Haneef with persons suspected to have been involved in the terrorist incidents in London and at Glasgow airport in June 2007. ${ }^{48}$ However, the ACT HRA did lead the Territory to develop an anti-terrorism regime that offers far greater protection for human rights than its State and federal counterparts, while still

\footnotetext{
$\overline{47}$ The decision of the High Court in Thomas $v$ Mowbray [2007] HCA 33 suggests that the doubts about the extent of the Commonwealth's constitutional power (at least in relation to the control order regime challenged in that case) were unfounded. The majority of the Court in that case upheld the validity of the control order regime under two heads of power, namely the powers to legislate with respect to defence and with respect to external affairs.

${ }^{48}$ See Haneef $v$ Minister for Immigration and Citizenship [2007] FCA 1273 (21 August 2007).
} 
apparently meeting the goals agreed by COAG. The ACT legislation thus stands as a challenge to the rhetoric of the Commonwealth that individual human rights must inevitably be sacrificed in such unusual times, to ensure the security of the community. 